\title{
Determinants of Personnel Differentiation for Competitive Advantage: From the Perspective of Customer Satisfaction.
}

\author{
Rifat Parveen Bokhari; Sarah Chowdhury
}

\begin{abstract}
Personnel differentiation has been viewed as one of the immeasurable competitive advantage for the service sector in the world. Such advantage or human resource based advantage is difficult for a competitor to imitate because the source of the advantage may not be very apparent to an outsider. If the service organization wants to achieve competitive advantage they must differentiate their personnel to satisfy their customer. Satisfied customer can loyal to the organization and loyal customer increases its profitability and sustainability. So, Different dimensions of personnel differentiation have been considered by various previous scholars. This study is an attempt to identify the factor causing personnel differentiation to satisfy customer for banking service for achieving competitive advantage. The study is exploratory in nature and uses Factor Analysis (Principal Component Analysis) to identify the most important factors of personnel differentiation which can help to achieve the competitive advantage of bank among 15 variables. The research methodology is empirical and a survey of different customers (sample-150) was conducted. The reliability test was used; the variable under study and sample size came reliable for the study. The findings reveal that six factors are considered important for determining personnel differentiation from the perspective of customer satisfaction. These factors are 'Visually Appealing personality and Tangibility '; 'Assurance'; 'Credibility and Accessibility'; 'Responsiveness' ; 'Empathy' and 'Reliability'.
\end{abstract}

Key words: Personnel Differentiation, Competitive Advantage, Customer Satisfaction, Factor Analysis, Principle component analysis.

\section{Introduction}

Human Resource play vital role in every service organization to satisfy the customer. Service organization like Banking is obvious for economic growth of any country. In Bangladesh, there are 53 commercial banks operating their business in the highly rivalry situation. So, every bank is trying to gain more customer than others and want to satisfy their customer by their product, service and offerings.

They need to gain competitive advantage for sustain their profit and growth. If the bank wants to gain more profit than other they have to provide better service and better service basically related with better trained personnel of a bank. In recent study, we see that these banks don't try to offer new service and products to the customers. They are reluctant about offering new service and products. So, in this situation bank have to differentiate their personnel to retain their existing customer.

Companies can gain competitive advantage through having better- trained personnel. Better trained personnel have six characteristics: Competence, courtesy, reliability, responsiveness, and communication (Kotler, Philip, 2000).

Lee, J. Krajewski and et.al (2011), in the organization, the customer is in close contact with the provider, the appearance and actions of the provider are especially important. Nicely dressed, friendly and sympathetic employees can affect the customer's perception of service quality. Personnel differentiation of bank play vital role in the time of competition for customer satisfaction to achieve competitive advantage. Various factors are prominent for personnel differentiation for achieving competitive advantage that may depend on customer satisfaction. This study will examine the factors which are playing most important role. After analyzing the data, we can draw a figure that personnel differentiation can satisfy customer and satisfied customer get more service from the organization and this helps to achieve competitive advantage. And last of competitive advantage can increase profitability and growth.

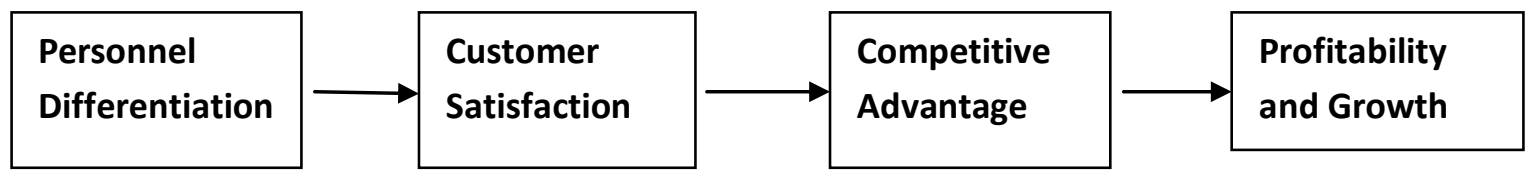

Figure-1: Relationship among personnel differentiation, customer satisfaction and competitive advantage. 


\section{Competitive advantage:}

\section{Conceptual Background}

Armstrong G., Adam S., Denize, S. and Kotler P.(2012), a competitive advantage can be gained by offering the consumer a greater value than the competitors, such as by offering lower prices or providing quality services or other benefits that justify a higher price. The strongest competitive advantage is a strategy that cannot be imitated by other companies

Kotler (2011), "To build a profitable relationship with target customers, marketers must understand customer needs better than competitors do and deliver more customers value. To the extent that a company can differentiate and position itself as providing superior customer value, it gains competitive advantage" Thus, competitive advantage is a certain value to the customer that a firm offers that is greater than the competitors.

Armstrong G., Adam S., Denize, S. and Kotler P. (2012), Competitive advantage occurs from differentiationProduct Differentiation; Service Differentiation ;Channel Differentiation ;People Differentiation and Image Differentiation

Company tries to differentiate itself to gain a competitive advantage through better-trained people who can serve their customers in an excellent manner. (Kotler, Philip, 2000), Better-trained personnel exhibit six characteristics. 1. Competence: Strategic efforts to create the impression those personnel have all the required skills and that skills are superior to the competition.2. Courtesy: Strategic efforts to create the impression that are friendly, respectful, and considerate for customer. 3. Credibility: Strategic efforts to create the impression those personnel are trustworthy.4.Reliability: Strategic efforts to create the impression that you are consistent and accurate. 5. Responsiveness: Strategic efforts to create the impression that are quick to respond to consumer requests.6. Communication: Strategic efforts to create the impression that will make an effort to understand and to communicate clearly with customer.

As a Money magazine article (2013), Herb Kelleher, CEO of Southwest Airlines, explains that the culture, attitudes, beliefs, and actions of his employees constitute his strongest competitive advantage.

Armstrong G., Adam S., Denize, S. and Kotler P. (2012), People differentiation is important when consumers deal directly with employees. Employees are the frontline defense against waning customer satisfaction. The consumer knows that the staff will be helpful and courteous, and this is very important to the consumer who may be trying a new home improvement technique with limited knowledge on the subject.

\section{Customer satisfaction:}

Customer satisfaction is the reflection of performance to expectation (McKaskill, 2011).Customer satisfaction programs are considered to be weapons that many companies use in fighting the battles in todays market place(Lenz, 1999) Customer satisfaction can be developed on its own without any effort, but usually it needs work and planning. Customer satisfaction is a competition and tool, the competitive advantage received from customer satisfaction is hard to duplicate for other companies, especially if the company devotes more effort into their customer service than their competition. If the company's personnel have outstanding personal chemistry, empathy, helpfulness and they can offer other pleasant gestures towards the customers, qualities that are hard to imitate for other companies. Even the ability to apologize or react correctly to negative feedback can indicate a sense of professionalism to the customer and that the customer is taken seriously (Lahtinen \& Isoviita 1998, 64). For many companies the situation nowadays is that their core competence needs to be refined into a service offering to develop their competitiveness and that the offering consists of all the value creating items that customers expect (Grönroos 2001) .The key to achieve sustainable advantage lies in delivering high quality service that results in satisfied customers (Shemwellet al, 1998).

Customer satisfaction has been viewed as an important indicator of corporate competitiveness, since it has a positive link to customer loyalty and profitability (Cronin and Taylor 1992; Oliver and Swan 1989; Anderson, Fornell, and Lehman 1994). Factors of customer satisfaction were traditional (basic) facilities, convenience, behavior of employees, and the environment of bank (Jham and Khan 2008).

\section{Objectives}

It is an attempt to determine the factors of Personnel Differentiation for Competitive advantage of Banking Sector in Bangladesh. The main objectives are:

- To study the trend of personnel differentiation

- To identify the variables of personnel differentiation, the relationship among personnel differentiation, customer satisfaction and competitive advantage.

- To find out which factors of personnel differentiation for customer satisfaction give most important for achieving competitive advantage. 


\section{Research Methodology}

This research is both qualitative and quantitative in nature and uses an empirical study method for fulfilling research objectives. The theoretical part clearly indicates that different variables would be important for personnel differentiation for competitive advantage for service organization. So, an attempt is made to study customer satisfaction and their perception of personnel differentiation in the context of Bangladesh. For the preparation of the paper, factor analysis as well as principal component analysis approach is conducted through a questionnaire survey. Principal Component Analysis (PCA) and Factor Analysis (FA) are statistical techniques used for data reduction or structure detection (Kim ,Jae and Mueller,1978; Abdi and Williams ,2010). The specific goals of PCA or FA are to summarize patterns of correlations among observed variables, to reduce a large number of observed variables or a number to a smaller number of factors It present a set of observed variables or a number of 'common' factors and a factor which is unique to each variable .The common factors (latent variables) are hypothetical variables which explain why a number of variables are correlated with each other .In factor analysis the coefficient are called loadings and a variable is said to load on a factor. Yong, An Gie and Pearce, Sean (2013). In the 'classical factor analysis' mathematical model, $\mathrm{p}$ denotes the number of observed variables $\left(X_{1}, X_{2}, \ldots, X_{p}\right)$ and $\mathrm{m}$ denotes the number of underlying common factors $\left(F_{1}, F_{2}, \ldots, F_{m}\right) . \mathrm{Xj}$ is the variable represented in latent factors. Hence, this model assumes that there are $m$ underlying factors whereby each observed variables is a linear function of these factors together with a residual variate. This model intends to reproduce the maximum correlations.

$$
X_{j}=a_{j 1} F_{1}+a_{j 2} F_{2}+\ldots \ldots a_{j m} F_{m}+e_{j}
$$

Where, $j=1,2, \ldots, p$. The factor loadings are $\left(a_{j 1}, a_{j 2}, \ldots, a_{j m}\right)$ which denotes that $a_{j 1}$ is the factor loading of $j$ th variable on the $1^{\text {st }}$ factor. The specific or unique factor is denoted by $e_{j}$. The factor loadings give us an idea about how much the variable has contributed to the factor; the larger the factor loading the more the variable has contributed to that factor (Harman, 1976). Factor loadings are very similar to weights in multiple regression analysis, and they represent the strength of the correlation between the variable and the factor (Kline, 1994). Factor analysis operates on the notion that measurable and observable variables can be reduced to fewer latent variables that share a common variance and are unobservable, which is known as reducing dimensionality (Bartholomew, Knott, \& Moustaki, 2011). When the coefficient are correlated (the factors are uncorrelated) the sum of the squares of the loadings for variable $X_{1}$, namely $a_{j 1+}, a_{j 2+}, \ldots,+a_{j m}$ shows the proportion of the variance of variable $X_{1}$ which is accounted by the common factor. This is called commonality. The larger the commonality for each variable, the more successful a factor analysis solution is. For Principal Component Analysis, the rotation used is Varimax rotation. Varimax are often used where multiple latent variables are present. This rotation is used to minimize the complexity of the components by making the large loadings larger and the small loadings smaller within each component and it constraints the correlation to be zero (0). It tries to maximize the variance of each of the factors so that the total amount of variance accounted could be redistributed over the extracted factors.

\section{Sample Size Selection, Data Collection and Variable Selection}

The universe in this case is defined as the entire customer of the country. Convenience sampling was used for the purpose of the survey and a research sample was taken to measure customer perception. The survey was carried out on different customers like Businessmen, Service Holder, Student and House Wife and others accountholders of different banks of Dhaka city.

We have chosen Dhaka city because Dhaka is the Capital of Bangladesh and most of the banks and their branches in here and also we have chosen these groups of customer to cover different customers of banks. A team of 40 BBA students of Ahsanullah University of Science and Technology visited these customers to collect all the samples in a convenient way to cover customer from all types. A total of 150 customers were contacted. The reliability of factor analysis is dependent on sample size (Field, 2005). We cannot take all of them in our study because of time and cost. In factor analysis, minimum sample size has to be more than 100, (Zikmund at.al, 2012).So we have decided to collect 150 questionnaire from respondent in different areas of Dhaka city .So, this was simply a research sample and may not truly represent the entire population; however, the test of significance has been done and shows that the sample size would not affect the results. including:

The questionnaire included 15 variables to measure personnel differentiation for competitive advantage 
Table1: Variables for personnel differentiation

\begin{tabular}{|l|l|l|}
\hline 1.Knowledge on particular Task & $\begin{array}{l}\text { 6. Pleasant Gestures, appearance } \\
\text { and attitudes }\end{array}$ & 11. Consistent and accurate service \\
\hline 2.Skill & 7. Time management ability & $\begin{array}{l}\text { 12. Ease access and good } \\
\text { communication skill }\end{array}$ \\
\hline 3.Culture of the organization & $\begin{array}{l}\text { 8. Handling customer carefully and } \\
\text { respectfully }\end{array}$ & $\begin{array}{l}\text { 13. Cooperation and keeping } \\
\text { customer request }\end{array}$ \\
\hline 4. Friendly and positive approach & 9. Considerable mind & 14. Willingness of solving problem \\
\hline 5. Cognition or additional knowledge & 10. Trustworthy and sincerity & $\begin{array}{l}\text { 15. Understanding ability of customer } \\
\text { preferences }\end{array}$ \\
\hline
\end{tabular}

A five- point Likert scale ranging from "Strongly Disagree" to "Strongly Agree". This scale is used because it allowed the researchers to quantify opinion-based items, and a scale with balanced keying (an equal number of positive and negative statements) could obviate the problem of acquiescence bias.

\subsection{Reliability Measure of Survey Questionnaire}

In this phase of analysis, the survey data are used to analyze the Reliability Scale (Alpha) and we see that the survey data are allowed greater precision and clarity in result. Reliability indicates the accuracy or precision of the measuring instrument (Norland, 1990). Cronbach's Alpha is the most common measure of internal consistency or reliability. Alpha coefficient ranges from zero(0) to one(1). The higher the score, the more reliable the generated scale is.

Table 2: Reliability Statistics

\begin{tabular}{|c|c|}
\hline Cronbanch's Alpha & N of Cases $=150.0$ \\
\hline Alpha $=.655$ & N of Items $=15$ \\
\hline
\end{tabular}

Source: Questionnaires

Table shows that the reliability value in the present study is found as 0.655 (Appendix A-1: Item total statistics).

\section{Analysis and Findings}

It is an attempt to concentrate on the dominant factors that cause personnel differentiation for competitive advantage from one bank to other bank from the perspective of customer satisfaction. We have chosen 15 variables and the reliability test justifies the accuracy of the chosen variables that has already been discussed in the previous section. Now, in here we interpret the sample adequacy that means whether the data are appropriate for doing Principal Component Analysis (Factor Analysis).

\subsection{Sampling Adequacy Measurement}

Table- 3: below presents the KMO and Bartlett's test. The Kaiser-Meyer-Oklin (KMO) measure of sampling adequacy is an index used to examine the appropriateness of factor analysis. Bartlett's test of Sphericity is a test statistic used to examine the strength of relationship among variables. This tests whether large for the correlations between question are sufficiently large for factor analysis to be appropriate and whether the

\section{Correlation Matrix(a}

Table-3: KMO and Bartlett's Test

\begin{tabular}{|l|l|r|}
\hline \multicolumn{2}{|c|}{ KMO and Bartlett's Test } \\
\hline \multicolumn{2}{|l|}{ Kaiser-Meyer-Olkin Measure of Sampling Adequacy. } & $\mathbf{. 6 5 6}$ \\
\hline $\begin{array}{l}\text { Bartlett's Test of } \\
\text { Sphericity }\end{array}$ & Approx. Chi-Square & 233.816 \\
\cline { 2 - 3 } & df & 105 \\
\cline { 2 - 3 } & Sig. & .000 \\
\hline
\end{tabular}

Source: Questionnaires

From the table-5, we see that the result of KMO test 0.656 . When it is over 0.5 , it will be acceptable. Hence it can be said that factor analysis is appropriate for these data. On the other hand, Bartlett's Test of Sphericity has the approximate Chi-Square score 233.816, degrees of freedom is 105 and this test is significant at 0.000 (have a significance value less than 0.05). This all point that Bartlett's test is highly significant $(\mathrm{p}<0.001)$ and therefore, factor analysis is appropriate. 


\subsection{Principal Components Analysis}

Now, we have analyzed the factor analysis by extracting the Principal Components using Varimax with Kaiser Normalization method. Yong, An Gie and Pearce ,Sean (2013), Varimax minimizes the number of variables that have high loadings on each factor and works to make small loadings even smaller. Principal Component Analysis works on the assumption that all variance are common and before extraction the communalities are all 1.Communalities are the proportion of variance explained by underlying factor. The amount of variance in each variable (retained factors) is represented by the communalities after extraction. The percent of variance in a given variable which is explained by all the factors jointly may be interpreted as the reliability of the indicator (Gason, 2008).Communality is a measure of the percentage of a variable's variations that explained by the factors. A relatively high communality indicates that a variable has much in common with the other variables taken as a group (Zikmund,William G. 2007). From the appended table -2, we have calculated the average extracted communalities to determine the eigenvalue cut-off based on which criteria to follow. The Kaiser criterion is said to be reliable when a) the average extracted communalities is at least more than .70 and when there are less than 30 variables or the averaged extracted communalities is equal or above .60 and the sample size is above 250 cases (Field,2009). In the appended table, A-2, we have found that Six meaningful factors which have at least more than.70 and variable are less than 30(15).

Total Variance Explained is used to determine the number of significant factors. In here we have used rotated eigenvalues and scree plot to determine the number of significant factors. An eigenvalue indicates how much of total variance of all variables is covered by the factors. The appended table A-3 showed the eigenvalues associated with each linear factor before and after extraction. The Extraction Sums of Squared Loadings is identical to the Initial Eigenvalues except factors that have eigenvalues less than $\mathbf{1}$. On the basis of these column, we can determine the corresponding the number of factors to be retained. And The Rotation Sums of Squared Loadings also showed the eigenvalues and variance after rotation to determine the number of significant factors. From the table, it is clear that only six factors are acceptable or generated from 15 variables. The first factors summarized $16.607 \%$ of the total variance where as the rest are $11.310 \%, 9.778 \%, \mathbf{7 . 9 6 2 \%}$, 7.7185 and $6.925 \%$ respectively.

Together the six factors summarized $60.300 \%$ of the total variance. So, The number of factors determined when the cumulative percentage of variance extracted by the factors reaches a satisfactory level . It is recommended to extract those factors that account for at least $60 \%$ of the variance ( Zikmund, at.al, 2012). In here we found that the cumulative percentage of variance is $60.300 \%$ for six factors which the original of 15 .

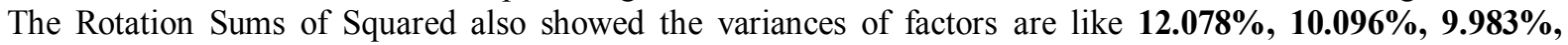
$9.831 \%, 9.731 \%$ and $8.581 \%$.

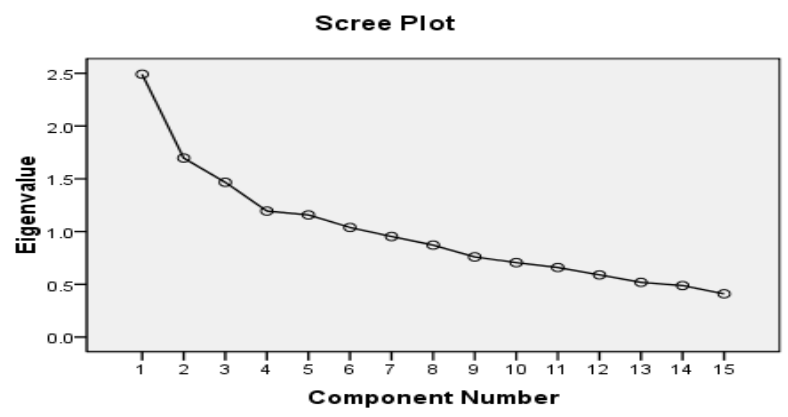

Figure-2: Scree Plot

A scree Plot is a plot of eigenvalues against the number of factors in the order of extraction. The plot consists of a distinct break between the steep slop of factors. So, the numbers of factors is determined at the point scree begins (Zikmund, at.al. 2012). In the above figure, it is clear that curve begin to flatten after the $7^{\text {th }}$ and $8^{\text {th }}$ factors. By considering the eigenvalue and variance analysis, we decided to retain only six factors.

In appendix, we showed Table A-4 and Table A-5.Table A-4: The Factor Matrix showed the factor loadings prior to rotation and Table A-5: the Rotated Component Matrix showed the rotated factors loadings which represent both the variables are weighed for each factor and also the correlation between the variables and the factors. Factor Loading more than 0.3 has been displayed . We have considered for our result values greater than 0.3 . We think these values are moderately correlated. This makes the output easier .

Appendix A-5 shows the six (6) rotated factors along with loading that have been extracted. Factors- 1 includes: Consistent and Accurate Service, Considerable Mind and Skill that might be named as "Reliability". The factor might be called as "Credibility and Accessibility" because the variable likes - Trustworthy and Sincerity and Ease Access and good Communication Skill. The third factor could be named as "Responsiveness" that includes Time Management Ability and Handling Customer carefully and respectfully. 
The fourth factor may be named as "Visually Appealing Personality and Tangibility" that includes Cognition or Additional Knowledge and Pleasant Gesture, Appearance, Attitudes. The fifth factor may be named as "Empathy" which includes Willingness of Solving Problem and Understanding Ability of Customer Preferences. And last of the factor six could be named as "Assurance" that includes Knowledge on Particular Task and Friendly and Positive Approach.

The rank order of factor is done by calculating the mean considering the correlation values of each factors loadings.

Table-4: Rank Order of Factors

\begin{tabular}{|c|c|c|}
\hline Factors & Mean & Rank Order of Factors \\
\hline Visually Appealing personality and Tangibility & .777 & 1 \\
\hline Assurance & .741 & 2 \\
\hline Credibility and Accessibility & .733 & 3 \\
\hline Responsiveness & .707 & 4 \\
\hline Empathy & .676 & 5 \\
\hline Reliability & .669 & 6 \\
\hline
\end{tabular}

From the table -4 , it is clear that the most dominating factor for customer satisfaction for achieving advantage in the competitive time 'Visually Appealing personality and Tangibility and'. Most of the bank in Bangladesh offers more or less same services and products to their customer. Customer may attract by their personnel's personality and tangibility of service. He or she takes service many more times from the bank and they meet with personnel. These personnel can attract, retain and motivate the customer to take service from the bank by their pleasant Gesture, appearance and attitudes; additional knowledge or cognition about service.

In here we see that second dominant factor might be -Assurance that may knowledge on particular task and friendly and positive approach. Customer may expect that employees will be knowledgeable on their task and they will be very friendly and their behavior will be positive in the time of providing service. Third dominating factors may be "Credibility and Accessibility" that may means customer may think that employee will be convenient to access them and they will be extrovert to communicate with them very easily. Other three dominating factors are responsiveness; empathy and reliability all those factors are important for customer satisfaction.

\section{Conclusion}

Today customers are keenly aware of their experience. The higher employee morale, greater customer satisfaction and increased customer retention. Now-a-days a growing number of organizations are giving increased attention to customer service through personnel differentiation. Financial institutions, hospitals, banks, public utilities, airlines, retail stores, restaurants, manufacturers, and wholesalers face the problem of gaining and retaining the patronage of customers. Building long-term relationships with customers has been given a high priority. Service encounter plays an important role in customer's satisfaction and measuring competitive advantage. The purpose of this study is to examine the competitive strategies adopted by banks to achieve competitive advantage in the banking service and to identify the actual determinants of customer satisfaction with quality of service provided. The study of customer satisfaction may be used as a basis to plan efforts towards increasing customer satisfaction. Although it is designed in a specific context may be extended to other similar services and help improve quality of bank service and thus increase overall satisfaction.

\section{References:}

[1]. Abdi.H., \& William, L.J, (2010), "Principal Component Analysis," Wiley Interdisciplinary Reviews: Computational Statistics, 2:433-459.

[2]. Armstrong G., Adam S., Denize, S. and Kotler P. (2012) Principles of Marketing, 5th Edition, Sydney, Pearson/Prentice Hall.

[3]. Armstrong G., Adam S., Denize, S. and Kotler P.(2012) Principles of Marketing, 5th Edition, Sydney, Pearson/Prentice Hall., pp. $184-196$

[4]. Bartholomew, D., Knotts, M., \& Moustaki, I. (2011). Latent variable models and factor analysis: A unified approach. (3rded.). West Sussex, UK: John Wiley \& Sons.

[5]. Child, D. (2006). The essentials of factor analysis. 3rd ed.. New York, NY: Continuum International Publishing Group.

[6]. Chong Ho Yu, Sandra Andrews, David Winograd, Angel Jannasch-Pennell, and Samuel A. DiGang.(2002). "Teaching Factor Analysis in Terms of Variable Space and Subject Space Using Multimedia Visualization". Journal of Statistics Education, Volume 10 , Number 1 .

[7]. Cronin, J. Joseph and Steven A. Taylor (1992), "Measuring Service Quality: A Reexamination and Extension,” Journal of Marketing, 56(3), 55-68.

[8]. Field, A. (2009).Discovering statistics Using SPSS: Introducing Statistical Method( $3^{\text {rd }}$ ed.)Thousand Oaks, CA: Sage Publication

[9]. Jham, V., and K. M. Khan.( 2008). Determinants of performance in retail banking: Perspectives of customer satisfaction and relationship marketing. Singapore Management Review, p://findarticles.com/p/articles/mi_qa5321/is_200807/ai_n27901656/. 
[10]. Kotler, Philip (2000), "Marketing Management: The millennium Edition,” Positioning the Market Offering Through The product Life Cycle, pp.286-295, Prentice Hall of India private Limited, New Delhi-110 0011999.

[11]. Malhotra K. Naresh, (2006), Marketing Research. ( $4^{\text {th }}$ ed.), Exploratory Research Design: Secondary Data (Chapter-4), (pp. 102), Measurement and Scaling: Non-comparative Scaling Techniques (Chapter-9), (pp. 258)

[12]. McKaskill,T.(2011).Marketing strategies: Customer Satisfaction. Retrieved from the smart Company website: http://www.smartcompany.com.au/advertising-and marketing /045933-21110923-marketing -strategies-customer -satisfaction$5 \mathrm{html}$

[13]. Norland- Tilburg, E. V. (1990). "Controlling error in evaluation instruments". Journal of Extension,(Online),28(2).http://www..joe.org./joe/1990summer/tt2.html.Nannaly,J.(1978). Psychometric theory. New York: McGraw -Hill.

[14]. Oliver, Richard L. and John E. Swan (1989), “Consumer Perceptions of Interpersonal Equity and Satisfaction inTransactions: A Field Survey Approach,” Journal of Marketing, 53(April), 21-35.

[15]. Yong , An Gie and Pearce, Sean (2013), “A Beginner's Guide to Factor Analysis :Focusing on Exploratory Factor Analysis", Tutorials in Quantitative Methods for Psychology, Vol. 9(2), p. 79-94.

[16]. Zikmund, William G., Babin, Barry J., Carr, Jon C., Adhikari, Atanu and Griffin Mitch (2012), Analysis of Interdependence, "Business Research Methods: South Asian Perspective", pp-649-59,8e, Cengage Learning India Pvt. Ltd.

[17]. Zikmund, William .G(2007).Business Research Method, $7^{\text {th }}$ ed, South- Western, A division of Thomson Learnin

\begin{tabular}{|c|c|c|}
\hline & Initial & Extraction \\
\hline Knowledge on particular & 1.000 & .702 \\
\hline skill & 1.000 & .461 \\
\hline Culture of the organization & 1.000 & .621 \\
\hline Friendly and positive approach & 1.000 & .658 \\
\hline Cognition or additional knowledge & 1.000 & .753 \\
\hline $\begin{array}{l}\text { Pleasant Gesture, appearance } \\
\text {,attitudes }\end{array}$ & 1.000 & .692 \\
\hline Time management ability & 1.000 & .666 \\
\hline $\begin{array}{l}\text { Handling customer carefully and } \\
\text { respectfully }\end{array}$ & 1.000 & .467 \\
\hline Considerable mind of an employee & 1.000 & .615 \\
\hline trustworthy and sincerity & 1.000 & .625 \\
\hline consistent and accurate service & 1.000 & .635 \\
\hline $\begin{array}{l}\text { Ease access and good } \\
\text { communication skill }\end{array}$ & 1.000 & .539 \\
\hline $\begin{array}{l}\text { Cooperation and keeping customer } \\
\text { request }\end{array}$ & 1.000 & .516 \\
\hline Willingness of solving problem & 1.000 & .608 \\
\hline $\begin{array}{l}\text { Understanding ability of customer } \\
\text { preference }\end{array}$ & 1.000 & .485 \\
\hline
\end{tabular}

Extraction Method: Principal Component Analysis.

A-3:Total Variance Explained

\begin{tabular}{|c|c|c|c|c|c|c|c|c|c|}
\hline \multirow[b]{2}{*}{ Component } & \multicolumn{3}{|c|}{ Initial Eigenvalues } & \multicolumn{3}{|c|}{ Extraction Sums of Squared Loadings } & \multicolumn{3}{|c|}{ Rotation Sums of Squared Loadings } \\
\hline & Total & $\begin{array}{c}\% \text { of } \\
\text { Variance }\end{array}$ & Cumulative $\%$ & Total & $\begin{array}{c}\% \text { of } \\
\text { Variance }\end{array}$ & $\begin{array}{c}\text { Cumulative } \\
\%\end{array}$ & Total & $\begin{array}{c}\% \text { of } \\
\text { Variance }\end{array}$ & $\begin{array}{c}\text { Cumulative } \\
\%\end{array}$ \\
\hline 1 & 2.491 & 16.607 & 16.607 & 2.491 & 16.607 & 16.607 & 1.812 & 12.078 & 12.078 \\
\hline 2 & 1.696 & 11.310 & 27.916 & 1.696 & 11.310 & 27.916 & 1.514 & 10.096 & 22.174 \\
\hline 3 & 1.467 & 9.778 & 37.694 & 1.467 & 9.778 & 37.694 & 1.497 & 9.983 & 32.157 \\
\hline 4 & 1.194 & 7.962 & 45.657 & 1.194 & 7.962 & 45.657 & 1.475 & 9.831 & 41.988 \\
\hline 5 & 1.158 & 7.718 & 53.375 & 1.158 & 7.718 & 53.375 & 1.460 & 9.731 & 51.719 \\
\hline 6 & 1.039 & 6.925 & 60.300 & 1.039 & 6.925 & 60.300 & 1.287 & 8.581 & 60.300 \\
\hline 7 & .953 & 6.355 & 66.655 & & & & & & \\
\hline 8 & .872 & 5.811 & 72.466 & & & & & & \\
\hline 9 & .760 & 5.064 & 77.530 & & & & & & \\
\hline 10 & .706 & 4.704 & 82.234 & & & & & & \\
\hline 11 & .659 & 4.395 & 86.629 & & & & & & \\
\hline 12 & .589 & 3.928 & 90.557 & & & & & & \\
\hline 13 & .518 & 3.456 & 94.014 & & & & & & \\
\hline 14 & .488 & 3.255 & 97.268 & & & & & & \\
\hline 15 & .410 & 2.732 & 100.000 & & & & & & \\
\hline
\end{tabular}


A-3:Total Variance Explained

\begin{tabular}{|c|c|c|c|c|c|c|c|c|c|}
\hline \multirow[b]{2}{*}{ Component } & \multicolumn{3}{|c|}{ Initial Eigenvalues } & \multicolumn{3}{|c|}{ Extraction Sums of Squared Loadings } & \multicolumn{3}{|c|}{ Rotation Sums of Squared Loadings } \\
\hline & Total & $\begin{array}{c}\% \text { of } \\
\text { Variance }\end{array}$ & Cumulative $\%$ & Total & $\begin{array}{c}\% \text { of } \\
\text { Variance }\end{array}$ & $\begin{array}{c}\text { Cumulative } \\
\%\end{array}$ & Total & $\begin{array}{c}\% \text { of } \\
\text { Variance }\end{array}$ & $\begin{array}{c}\text { Cumulative } \\
\%\end{array}$ \\
\hline 1 & 2.491 & 16.607 & 16.607 & 2.491 & 16.607 & 16.607 & 1.812 & 12.078 & 12.078 \\
\hline 2 & 1.696 & 11.310 & 27.916 & 1.696 & 11.310 & 27.916 & 1.514 & 10.096 & 22.174 \\
\hline 3 & 1.467 & 9.778 & 37.694 & 1.467 & 9.778 & 37.694 & 1.497 & 9.983 & 32.157 \\
\hline 4 & 1.194 & 7.962 & 45.657 & 1.194 & 7.962 & 45.657 & 1.475 & 9.831 & 41.988 \\
\hline 5 & 1.158 & 7.718 & 53.375 & 1.158 & 7.718 & 53.375 & 1.460 & 9.731 & 51.719 \\
\hline 6 & 1.039 & 6.925 & 60.300 & 1.039 & 6.925 & 60.300 & 1.287 & 8.581 & 60.300 \\
\hline 7 & .953 & 6.355 & 66.655 & & & & & & \\
\hline 8 & .872 & 5.811 & 72.466 & & & & & & \\
\hline 9 & .760 & 5.064 & 77.530 & & & & & & \\
\hline 10 & .706 & 4.704 & 82.234 & & & & & & \\
\hline 11 & .659 & 4.395 & 86.629 & & & & & & \\
\hline 12 & .589 & 3.928 & 90.557 & & & & & & \\
\hline 13 & .518 & 3.456 & 94.014 & & & & & & \\
\hline 14 & .488 & 3.255 & 97.268 & & & & & & \\
\hline
\end{tabular}

Extraction Method: Principal Component Analysis.

A-4:Rotated Component Matrix ${ }^{a}$

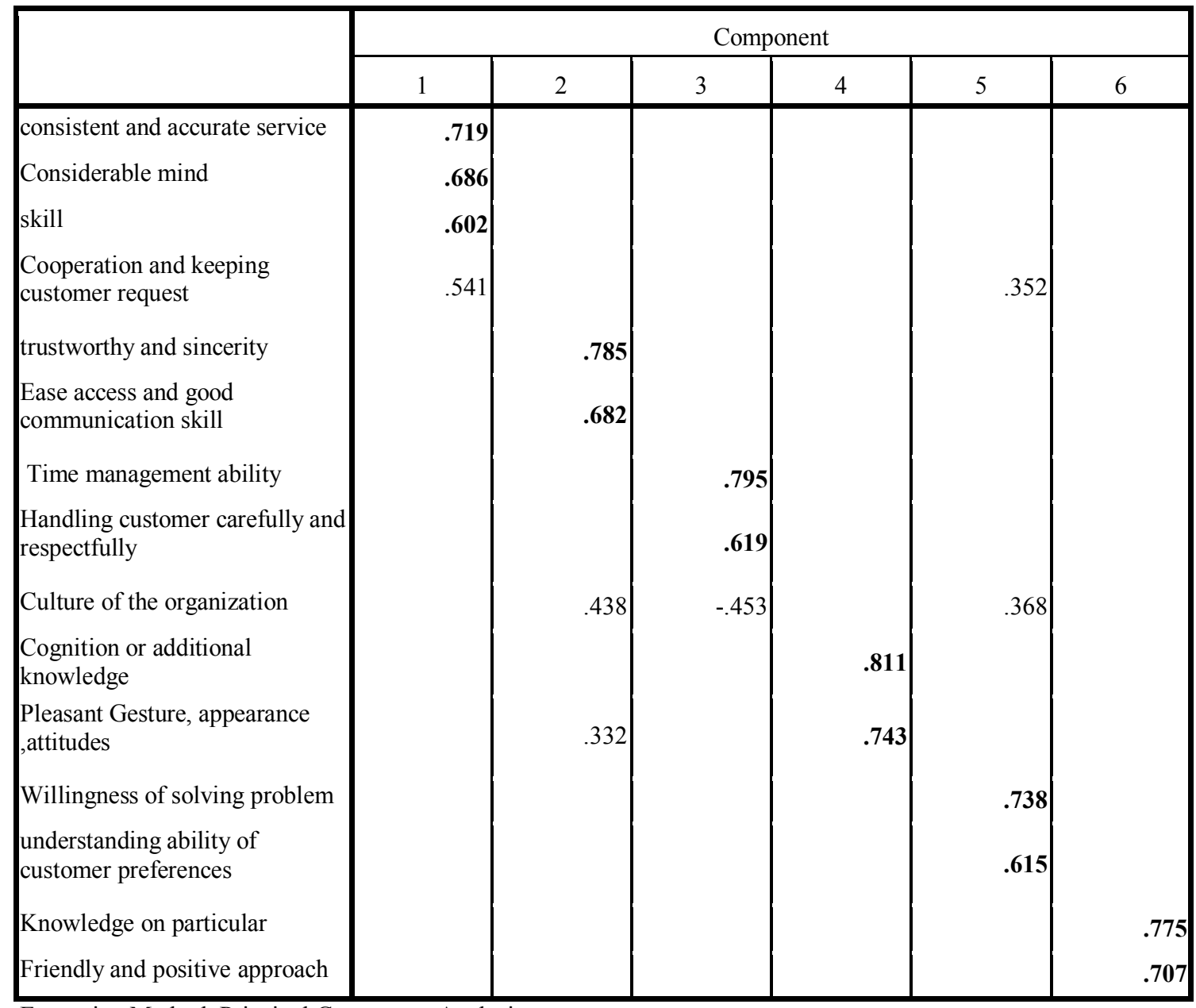

Extraction Method: Principal Component Analysis.

Rotation Method: Varimax with Kaiser Normalization.

a. Rotation converged in 7 iterations. 